International Journal of Canadian Studies

Revue internationale d'études canadiennes

\title{
The Earth Keepers Solid Waste Management Planning Program: A Collaborative Approach to Utilizing Aboriginal Traditional Knowledge and Western Science in Ontario
}

\author{
Deborah McGregor
}

Numéro 41, 2010

Representations of First Nations and Métis

Les représentations des Premières Nations et des Métis

URI : https://id.erudit.org/iderudit/044163ar

DOI : https://doi.org/10.7202/044163ar

Aller au sommaire du numéro

Éditeur(s)

Conseil international d'études canadiennes

ISSN

1180-3991 (imprimé)

1923-5291 (numérique)

\section{Découvrir la revue}

\section{Citer cet article}

McGregor, D. (2010). The Earth Keepers Solid Waste Management Planning Program: A Collaborative Approach to Utilizing Aboriginal Traditional Knowledge and Western Science in Ontario. International Journal of Canadian Studies / Revue internationale d'études canadiennes, (41), 69-98.

https://doi.org/10.7202/044163ar

\section{Résumé de l'article}

Tant le « Rapport Brundtland » de 1987 que le chapitre 26 de l'« Action 21 » (qui a résulté du « Sommet de la Terre » de 1992) ont officiellement reconnu le rôle des populations autochtones dans le développement durable mondial. L'Action 21 recommande, d'une part, que les valeurs, les connaissances traditionnelles et les pratiques de gestion des ressources autochtones soient reconnues et mises sérieusement à contribution dans des activités de développement durable et, d'autre part, que le renforcement des capacités des collectivités autochtones soit basé sur l'adaptation et l'échange du savoir traditionnel afin d'accroître leur participation au développement durable. Cet article étaye l'élaboration et les principes sous-jacents d'un programme pratique visant à répondre de front à ces deux critères. Financé par le gouvernement canadien et élaboré par une société autochtone possédant une expertise scientifique occidentale, le programme des " Gardiens de la Terre » représente un progrès décisif vers l'établissement d'un véritable programme de collaboration dans l'intérêt des citoyens tant autochtones que non autochtones. Bien que des participants au programme constatent qu'il y a des aspects qui gagneraient à être améliorés, la clé du succès des stratégies du programme jusqu'à ce jour a été d'inclure concrètement des partenaires des collectivités autochtones dès le départ. Le système de rétroaction intégré a permis au programme de s'adapter pour mieux répondre aux besoins des participants au fil du temps. Un examen constant du programme à mesure qu'il évolue s'impose, car il représente non seulement un changement radical par rapport aux approches " coloniales " dépassées à l'égard de la recherche et du développement dans des collectivités autochtones, mais aussi un pas novateur vers un meilleur avenir sur le plan environnemental pour tous les participants.
Tous droits réservés (C Conseil international d'études canadiennes, 2010
Ce document est protégé par la loi sur le droit d'auteur. L'utilisation des services d’Érudit (y compris la reproduction) est assujettie à sa politique d'utilisation que vous pouvez consulter en ligne.

https://apropos.erudit.org/fr/usagers/politique-dutilisation/ 


\title{
Deborah McGregor
}

\section{The Earth Keepers Solid Waste Management Planning Program: A Collaborative Approach to Utilizing Aboriginal Traditional Knowledge and Western Science in Ontario}

\begin{abstract}
Both the 1987 "Brundtland Report", and Chapter 26 of Agenda 21 (which emerged from the 1992 "Earth Summit"), formally recognized the role of Indigenous people in global sustainable development. Agenda 21 requires that Aboriginal values, traditional knowledge, and resource management practices are recognized and meaningfully involved in sustainable development undertakings; and that capacity-building in Aboriginal communities, based on the adaptation and exchange of traditional knowledge, is developed so as to increase the ability of Aboriginal peoples to participate in sustainable development. This paper documents the principles behind and development of a practical program aimed at meeting these two criteria head on. Funded by the Canadian government and developed by an Aboriginal corporation with western scientific expertise, the "Earth Keepers" program represents a significant move towards establishing a truly collaborative program with benefits for Aboriginal and non-Aboriginal constituents alike. While participants in the program recognize areas for improvement, key among the program's successful strategies to date has been the meaningful inclusion of Aboriginal community partners from the outset. The program's built-in feedback system allows it to adapt to better meet the needs of participants over time. Continued scrutiny of this program as it evolves is warranted as it represents a significant departure from outmoded "colonial" approaches to research and development in Aboriginal communities, and an innovative step towards an improved environmental future for all participants.
\end{abstract}

\section{Résumé}

Tant le "Rapport Brundtland" de 1987 que le chapitre 26 de l'" Action 21 » (qui a résulté du "Sommet de la Terre » de 1992) ont officiellement 
reconnu le rôle des populations autochtones dans le développement durable mondial. L'Action 21 recommande, d'une part, que les valeurs, les connaissances traditionnelles et les pratiques de gestion des ressources autochtones soient reconnues et mises sérieusement à contribution dans des activités de développement durable et, d'autre part, que le renforcement des capacités des collectivités autochtones soit basé sur l'adaptation et l'échange du savoir traditionnel afin d'accroitre leur participation au développement durable. Cet article étaye l'élaboration et les principes sous-jacents d'un programme pratique visant à répondre de front à ces deux critères. Financé par le gouvernement canadien et élaboré par une société autochtone possédant une expertise scientifique occidentale, le programme des "Gardiens de la Terre " représente un progrès décisif vers l'établissement d'un véritable programme de collaboration dans l'intérêt des citoyens tant autochtones que non autochtones. Bien que des participants au programme constatent qu'il y a des aspects qui gagneraient à être améliorés, la clé du succès des stratégies du programme jusqu'à ce jour a été d'inclure concrètement des partenaires des collectivités autochtones dès le départ. Le système de rétroaction intégré a permis au programme de s'adapter pour mieux répondre aux besoins des participants au fil du temps. Un examen constant du programme à mesure qu'il évolue s'impose, car il représente non seulement un changement radical par rapport aux approches " coloniales " dépassées à l'égard de la recherche et du développement dans des collectivités autochtones, mais aussi un pas novateur vers un meilleur avenir sur le plan environnemental pour tous les participants.

\section{Introduction}

For thousands of years, Indigenous peoples around the world have lived sustainably on their territories (Clarkson et al. LaDuke, 1994; McGregor, 2004a). The knowledge Indigenous peoples developed to ensure their continued survival has transformed over time to meet new challenges; in many ways it remains as relevant today as it has been historically. Recognition of the role that Indigenous peoples and their knowledge may play in addressing global environmental issues has increasingly been emerging as part of international discourse, in part through continued lobbying by Indigenous delegations to the United Nations. Such recognition was most recently, and perhaps most significantly, expressed through the UNDeclaration on the Rights of Indigenous Peoples, approved in 2007 (UNGA, 2007). Major UN initiatives in this area, though, go back to at least 1983, when the World Commission on Environment and 
Development was established to develop a "global agenda for change" (WCED, ix) with respect to environment and development-related issues. In 1987, the Commission released Our Common Future, which has been highly influential in articulating the potentially vital roles Indigenous peoples can play in sustainable development:

These communities are the repositories of vast accumulations of traditional knowledge and experience that links humanity with its ancient origins. Their disappearance is a loss for the larger society, which could learn a great deal from their traditional skills in sustainably managing very complex ecosystems. (114-115)

Five years after the release of Our Common Future, the 1992 United Nations Conference on Environment and Development (UNCED; the "Earth Summit") was held in Rio de Janeiro, with the goal of beginning to work in earnest on addressing global environmental issues. The Earth Summit also represented a breakthrough for Indigenous peoples' participation in sustainable development discourse.

The "Convention on Biological Diversity" (CBD) and "Agenda 21", emerged for Canada as the most significant products of the 1992 conference. As an international agreement signed by a majority of the world's governments, including Canada, the CBD sets out commitments for maintaining the planet's ecosystems. It reiterates the important role of Indigenous people and their knowledge for achieving sustainable environmental and resource management (NAHO). This role was reaffirmed at the 2002 follow-up conference, the World Summit on Sustainable Development (WSSD), held in Johannesburg, South Africa.

Other factors shaping Canada's move towards including traditional knowledge (TK) in environmental initiatives have included court decisions such as Delgamuukw, which was fundamental in achieving greater recognition for the validity of the oral transmission of TK (DoyleBedwell and Cohen). Also in the courts, recognition of Aboriginal and treaty rights has shaped land claims policy, and modern-day treaty-making now involves TK as an integral component of many co-management regimes in the Canadian North (Nadasdy, 1999; Spak; White). In Canada, the discussion around TK thus exists within the context of increasing Aboriginal control over lands and resources through self-government agreements, comprehensive land claims and other mechanisms. This trend towards increasing Aboriginal control represents a considerable opportunity for the expression of $\mathrm{TK}$ in environmental and resource management, as both Aboriginal and non-Aboriginal resource managers 
recognize a pressing need to incorporate $\mathrm{TK}$ as part of new and more progressive systems of management (Menzies and Butler; Sable et al.). The study of TK is therefore not just an esoteric or academic exercise; it can be utilized as a powerful tool in the establishment of Aboriginal influence in environmental and resource management regimes (Battiste and Henderson; Houde; Manseau et al.; O'Flaherty et al.; Usher 2000).

Aboriginal influence and control in environmental and resource management in Canada is varied and uneven. In the North, where a number of comprehensive land claims have been settled and selfgovernment agreements negotiated, new institutions of governance have been established that specifically provide for Aboriginal involvement and the inclusion of TK (Natcher and David; Spak). One noteworthy example is the Gwich'in Renewable Resources Board (GRRB) ${ }^{1}$ which has ensured that TK forms an essential part of environmental and resource management in the settlement area. ${ }^{2}$ The GRRB has also developed its own traditional knowledge policy: Working with Gwich'in Traditional Knowledge in the Gwich'in Settlement Region (GRRB).

Another example of institution building is to be found in the Nunavut Land Claims Agreement (NT) which guarantees Inuit involvement in land and resource management decision making in the Nunavut settlement area. The Nunavut Wildlife Management Board ${ }^{3}$ explicitly recognizes TK as an important source of information to be drawn upon for decision making. The Board recognizes "the role and power of various sources of information and expertise, including but not limited to, resource users, community elders, traditional knowledge and modern science" (www.nwmb.com). Although such co-management institutions represent an important step forward in terms of Aboriginal environmental and resource management, such boards are not without their difficulties in addressing TK (Nadasdy 2006; Stevenson 2006). Self-government agreements are also providing opportunities for Aboriginal involvement in environmental and resource management (ERM). The Northern Tutchone Council (NTC) in the Yukon, for example, is in the process of "reimplementing traditional laws related to the use and occupation of settlement lands" (Natcher and Davis, 274) as an important part of the their transition to self-government. Not all self-government processes incorporate such innovation and many simply as extensions of existing government administration (Natcher and Davis). However, the creation of new institutions as part of comprehensive land claim and self-government processes does form an important part of an emerging Aboriginal environmental and resource management paradigm in Canada. 
In some parts of Canada, including Ontario, institution building for the purposes of Aboriginal environmental and resource management has been more difficult to establish, and is practically non-existent. The Aboriginal resource management context differs significantly from those areas in Canada where treaties and other agreements have not been concluded with the Crown. Where treaties already exist, it is the Crown's view that traditional Aboriginal rights to lands and resources have historically been extinguished. As a result, Metis scholar and activist, Jean Telliet, observes that environmental conservation and protection processes in Ontario have in fact been used as a means to deny Aboriginal people's authority and jurisdiction over their territories. The natural resource regulatory regime in Ontario has historically sought to dispossess Aboriginal people of their lands and "the dispossession is not finished" (Teillet 4). As Anishinabe legal scholar John Borrows states, "the Crown now claims occupation of traditional Aboriginal lands" (Borrows 3). Aboriginal peoples in Ontario thus find themselves in the difficult position of striving to maintain ties to their territories through participation in Crown-led environmental and resource management regimes. However, the desire of Aboriginal peoples, "... to hold [onto] their lands and resources [and] to be more productive and preserve their ancient relationships" remains (Borrows 3). Aboriginal peoples involvement in ERM in Ontario in spite of the obstacles represents a small step in continuing to advance their vision of "reoccupation" (Borrows).

As a way of further advancing such goals, Aboriginal peoples have been quick to embrace international conventions such as the aforementioned Agenda 21 (Higgins). For its part, Agenda 21 describes goals, objectives and implementation strategies that serve as a plan of environmental action at global, national and local levels. In particular, Chapter 26 formally recognizes the role that Indigenous people can play in such action. Both Agenda 21 and the CBD formally acknowledge that Indigenous people have a historical relationship to their lands and have, over many generations, developed a wealth of traditional knowledge of those lands. Both agreements also recognize that despite this, Indigenous people have thus far not been able to participate as fully as desired in sustainable development. In Ontario as in the rest of Canada, a number of significant barriers to $\mathrm{TK}$ inclusion in environmental resource management remain. These include the lack of an agreed-upon definition or description of TK (Berkes; McGregor 2004b; Usher; White); issues around ownership and control of knowledge, or intellectual property rights (WIPO); the continued devaluing of TK as compared to western science (Nadasdy 1999; Roberts); and an overall lack of basic understanding of 
Aboriginal peoples, their world views, and knowledge systems (Davis et al.; Kimmerer). For further discussion on issues around TK application, see Ellis; McGregor (2000); Nadasdy (2006) and Stevenson (2005).

International conventions and initiatives such as the CBD and Agenda 21 have had significant implications for Canada and Ontario in relation to sustainable environmental and resource management (Higgins), and in particular for ongoing efforts to overcome barriers to TK use. Among the outcomes of such implications, Canada has written stipulations for the consideration of Aboriginal traditional knowledge into the Species At Risk Act (2003), the Canadian Environmental Assessment Act (1995), and policy initiatives such as the National Forest Strategy (NFSC).

Canada reaffirmed its sustainable development commitments through the passing of the Federal Sustainable Development Act in June 2008. This Act requires Canada to develop and monitor the progress of a governmentwide sustainable development strategy. It also creates a Sustainable Development Advisory Council including Aboriginal representation. It seems more than ever that achieving sustainable development goals is important in Canada and recognition of the integral role Aboriginal peoples have in achieving such a goal is as relevant today as it was 15 years ago. However, translating such political recognition into practical local undertakings remains a challenge for most governments (Gunton and Joseph).

As over 15 years have now passed since the Earth Summit, it is necessary to monitor what progress has been made towards meeting the Aboriginal knowledge goals and objectives of that conference and the subsequent WSSD in 2002. There are two primary objectives with respect to Aboriginal people which can be drawn from Agenda 21. These are aimed at ensuring, "[i]n full partnership with indigenous people ...":

a) "Establishment of a process to empower indigenous people and their communities through measures that include ... recognition of their traditional knowledge ... and ... capacity-building", and

b) "Establishment ... of arrangements to strengthen the active participation of indigenous people and their communities in the national formulation of policies, laws and programmes relating to resource management ... and ... sustainable development...." (UNDESA 1-2)

While there have been a great many TK-related undertakings in Ontario since the Earth Summit, these projects have generally struggled, and 
continue to struggle, with identifying and implementing appropriate methods of including Aboriginal people and their knowledge (Duckworth et al.; McGregor, 2008, O’Flaherty et al.; PFN and OMNR).

This research discusses one option for considering TK in ERM. International conventions are indeed encouraging environmental governance in Canada to reflect Aboriginal interests and TK. However, such conventions also fall short of supporting Aboriginal selfdetermination in the area of ERM and TK. They support Aboriginal involvement in state-led ERM processes rather than the establishment of Indigenous processes. Indigenous scholars in Canada recognize this situation and have called for "decolonizing" processes and institutions in an effort to move from simply Aboriginal participation to Aboriginalled ERM (McGregor, 2004; Simpson). Efforts to decolonize various state-led ERM institutions necessarily have humble beginnings, starting, for example, by influencing environmental governance and securing Aboriginal voice, knowledge, values and perspectives in such processes.

This paper focusses on one such humble start. It describes a program that is unique in Ontario in its attempt to address both the traditional knowledge and capacity-building aspects of the objectives set out in Agenda 21, and in its achievement of such a positive response from its participants.

This program, the "Earth Keepers Solid Waste Management Planning Program", has been in existence for close to a decade. It was developed in the Province of Ontario, Canada, by the Ontario First Nations Technical Services Corporation (OFNTSC). A non-profit corporation created in 1995, the OFNTSC's mission is to provide professional technical advisory services to all First Nations ${ }^{4}$ in Ontario and to foster technical self-reliance among Aboriginal people. One of the first organizations of its kind, the responsibilities it assumed were previously held by Canadian government agencies. The establishment of OFNTSC represents a key step in the move by Ontario First Nations towards self-determination (OFNTSC, 2008).

The Earth Keepers program is aimed at developing the capacity of First Nations to conduct community consultations leading to the development of a waste management plan in their communities. It is also intended as a way in which First Nations can bring traditional knowledge to the forefront in the development of such programs so as to make them more sustainable. This paper will provide an overview of the Earth Keepers 
program, including some background to its development, discussion of its conceptual framework, challenges faced in its implementation, and initial feedback from participants who have been involved in its early stages. As the Earth Keepers program is continually evolving in order to address First Nations' needs, some suggestions for improvements based on the early participant feedback will be included. Initially, however, some context is provided as to why a program such as Earth Keepers was needed in the first place.

\section{Prior to Earth Keepers: Aboriginal Community Concerns Around Solid Waste Management}

In Canada, it has long been recognized that First Nations are plagued with numerous environmental problems (CESD; CIER; HETF; Kassi). These have been due to such factors as a lack of environmental regulation in comparison to the rest of the country, breakdowns in community values and structures as a result of colonization, and a diminishing land base supporting the fastest growing population in the country, to name a few (AFN; RCAP 1996a). Early in the development of the Earth Keepers program, community perspectives on the challenges faced in solid waste management were obtained and are outlined as follows (OFNTSC 2002):

- Current approaches to waste management planning are not culturally appropriate. Technical operating manuals which conflict with oral tradition are still prevalent in First Nation communities. First Nations should develop their own standards for waste management that reflect their own values, beliefs and cultural traditions.

- There is a lack of understanding of the cost of poor solid waste management practices. The costs of a degraded environment in social, health and cultural terms far exceed the cost of an effective waste management system.

- Waste management frameworks are lacking at the community level. Planning (if any) is haphazard and the community is often not engaged in decision making.

- More education is needed. There is a need for greater education and awareness of waste management issues. Such education should begin with children and youth as they will in turn teach adults in their communities. Traditional and cultural education will play an important part. Traditional knowledge is important 
in formulating appropriate responses to waste management issues.

- There is a lack of links to other opportunities in the community. Effective and appropriate solid waste management programs can bring benefits to the community in other areas, including the provision of economic development opportunities (e.g. programs in recycling, employment, social responsibility, elder/youth mentoring).

- Dumping of waste by non-Aboriginals on Aboriginal lands continues to be a significant problem. Many First Nations lack the policy and regulatory frameworks to manage this prevalent and disturbing issue.

- $\quad$ Funding is needed to develop appropriate waste management plans and programs at the community level.

- There is a lack of culturally appropriate training and awareness programs delivered to First Nations. Training programs need to address management as well as technical issues concerning successful program operation at the community level.

- There is a lack of monitoring and evaluation of current solid waste management systems.

- There is a lack of enforcement of First Nation by-laws or other regulations concerning inappropriate waste management practices (e.g., burning).

\section{The Earth Keepers Program: A Brief Overview}

Development of the Earth Keepers program was undertaken with the aim of addressing concerns such as those listed above. Funded by Indian and Northern Affairs Canada, ${ }^{5}$ the program was intended from the outset to provide First Nations with the opportunity to develop an alternative to conventional waste management planning practices. The resulting Earth Keepers program indeed represents a shift from the status quo in that it requires a more community-driven process and is designed to advance community capacity building.

Earth Keepers is an action-oriented program which provides interested First Nation communities with the opportunity to participate in training. Not only are participants trained in the theory of designing and implementing a solid waste management program, but during the training they also undertake the practical process of creating a Solid Waste 
Management Plan for their communities. This plan can be completed and ready for implementation by the end of the training program. Participants thus come away from the training with an immediate benefit for their communities.

During the program, community representatives are guided through a series of training modules on how to conduct a community based solid waste management planning process. They are also provided with the technical information they need to develop such plans. The training modules are set up so that community representatives participate in formal training for two to three days and then go back to their communities to conduct planning activities with other community members for six weeks. They then return to the formal training sessions. This cycle is repeated three times. Upon completion of the training, each participant's community should have the tools to complete a Solid Waste Management Plan.

This unique training and community development program is a prime example of how Ontario First Nations, in collaboration with the Government of Canada, have engaged in a program that addresses the two key aspects of Agenda 21 noted above: the incorporation of traditional knowledge and the building of community capacity to participate in sustainable development practices.

\section{Guiding Principles of the Earth Keepers Program}

The overall purpose of Agenda 21 is to move the global community toward sustainable development. Sustainable development has frequently been defined in international circles as development that meets the needs of today without compromising the needs of future generations (WCED). It has been recognized by Aboriginal groups that they themselves need to define what they mean by sustainable development, and that this definition will likely differ from that derived in the international arena. In 1997, the Chiefs of Ontario was asked to prepare a submission to INAC on First Nations concepts of sustainable development. The concept of sustainable development articulated by the Chiefs of Ontario (9) states that:

Our spiritual teachings tell us that we must regard everything as spirit. We must respect the tree spirit and the animal spirit. Our relationship with the world around us is a personal one. 
Aboriginal people base their philosophy on the idea of sharing and mutual obligation. The concept of sharing extends in the future. The fundamental value of Aboriginal people is a great respect for life, land and sharing. The spiritual laws of First Nations are put forward to protect the environment.

Key principles in this concept of sustainable development include:

- We have a responsibility to share;

- We have a collective responsibility to the whole of Creation; and

- We have a responsibility to be respectful of Creation's desire to live, and to have a quality of life. (Chiefs of Ontario)

Other perspectives include one shared by Oneida student, Rolanda Elijah, as part of a Chiefs of Ontario paper:

Sustainability is not an isolated concept. In Aboriginal culture, "sustainability" is a set of integrated beliefs and practices within a paradigm that is shaped by spiritual and biophysical forces.

The plants and animals give instructions to the people as to how they should be respected and cared for. These teachings are passed on from generation to generation. Sometimes the teachings provide ecological information about the species. (Elijah 23)

McGregor (2004a, 76) shared this view:

Indigenous views of sustainable development are not based on TAKING, but on GIVING. Indigenous people ask themselves what they can give to the environment and their relationship with it. The idea of sustaining, maintaining and enhancing relations with all of Creation is of utmost importance from an indigenous point of view. Indigenous ways of life focus on this type of relationship with Creation. Indigenous people understand that with this special personal relationship with Creation comes tremendous responsibility; it is not something to be taken lightly.

Aboriginal notions of sustainable development such as these form an integral part of the Earth Keepers program. Aboriginal people thus see a clear and direct link between sustainable development and traditional knowledge. Grounded in broad notions such as Aboriginal concepts of sustainable development, the delivery of the Earth Keepers program is guided by specific principles developed in consultation with First Nations communities. These principles address the two key objectives of Agenda 
21 noted earlier: the need to involve Aboriginal traditional knowledge in sustainable development initiatives, and the need to engage in First Nations capacity building so as to permit First Nations to participate more fully in such undertakings. Key principles of the program are highlighted below.

\section{Earth Keepers and Traditional Knowledge}

Agenda 21 (specifically Chapter 26) calls for a significant global commitment to Indigenous people through recognizing and strengthening their role in sustainable development. In working towards this, a number of objectives were identified in Agenda 21 which would result in the recognition, respect and utilization of Aboriginal traditional knowledge in environmental and resource management and capacity-building processes.

The philosophical foundation for the development and community level implementation of the Earth Keepers program stems from the importance of recognizing and reclaiming traditional knowledge at the community level. Key principles from the Earth Keepers program in support of this therefore include:

Reclaiming responsibility for the environment: A major tenet of Aboriginal traditional philosophy is responsibility (Clarkson et al.). While traditional knowledge still remains with the people, many no longer know how to apply it to address current challenges such as solid waste management. An important part of the Earth Keepers program is therefore geared towards helping participants renew their understanding of traditional knowledge in a present day context. Participants are encouraged to learn to reassume their responsibilities in relation to traditional knowledge in the hope that this will lead to community-based decisions promoting sustainable development.

Relearning traditional knowledge: While traditional knowledge continues to be held by First Nations communities, it is recognized that Indigenous people around the world have experienced many hardships that have resulted in severe disruptions in their way of life and in the ways that traditional knowledge is understood and practiced (Battiste and Hendeson). This has been the case for First Nations people in Canada. The Earth Keepers program therefore advocates re-learning traditional knowledge wherever possible. The program itself is described as a learning guide or in some 
cases a relearning guide. While an ambitious undertaking for a single program, the Earth Keepers program will make significant contributions to these goals where it is implemented in First Nations communities.

\section{Earth Keepers and Capacity Building}

Earth Keepers aims to assist in capacity building both within and among First Nations communities. Key guiding principles in the Earth Keepers program related to capacity building include:

Drawing on the value of community knowledge: The approach utilized by the Earth Keepers program establishes a direct link between traditional knowledge and capacity building. The program uses materials and training strategies that will utilize each community's own collective knowledge and experience to guide the development of a solid waste management program. This training model represents a significant departure from how such programs are presently delivered in many First Nations communities.

Many Aboriginal capacity-building models assume that the knowledge required by Aboriginal people to manage environmental resources and challenges originates outside the community. In many cases, externally driven advice is highly technical and does not reflect community realities. The results from such efforts are documents or reports that frequently see little use at the community level. In the Earth Keepers program a conscious decision was made to avoid perpetuating externally driven processes. The Earth Keepers model begins with the idea that communities already have the foundations upon which to build community capacity and address the environmental challenges they face.

In this new model for capacity building, the existing (and in many cases untapped) experience and expertise of community members will be utilized to shape the development of the solid waste management program. Community knowledge, which frequently constitutes traditional knowledge, will guide the decision-making framework for community action.

Reducing reliance on external interventions: The Earth Keepers program recognizes that external expertise will be required from time to time. However, the fundamental premise is that community knowledge will provide the overall guiding framework (or 
worldview) for development, rather than technical reports prepared by external and often non-Aboriginal consultants.

Promoting community development: Not only does Earth Keepers intend each community to guide the program conceptually, but it is also designed so that each community can conduct much of the work involved in designing and implementing the solid waste management system themselves. Earth Keepers has produced a number of learning tools and an instructional video and CD-ROM (OFNTSC, 2002). These learning resources, which are founded on Aboriginal perspectives, are intended to assist communities in developing their own systems. By assisting communities in performing as much of their own work as possible, Earth Keepers promotes community development, rather than being simply a waste management program.

In summary, the Earth Keepers program embodies the objectives of Agenda 21 in terms of its philosophy and approach to capacity building and traditional knowledge involvement. It aims to help communities move towards greater sustainability. Though the specific focus is on developing solid waste management systems, the Earth Keepers program offers First Nations the opportunity to achieve broader collective goals by revitalizing cultural traditions both during the course of training itself and in the actual implementation of solid waste management plans. The program thus balances this broader collective effort with the resolution of tangible, on-the-ground problems.

\section{Contribution of the Earth Keepers Program to Understanding Traditional Knowledge}

\section{Traditional Knowledge Terminology}

One of the main areas where Aboriginal people challenge current thinking on traditional knowledge is in the terminology itself. Traditional knowledge is frequently referred to among non-Aboriginal researchers as "traditional environmental knowledge" (or "traditional ecological knowledge"), abbreviated as TEK (Berkes; Houde; Shackerof and Campbell; White). To date there has been no consensus among various interests on exactly what TEK is. ${ }^{6}$ The concept itself is difficult to translate into Aboriginal languages spoken in Canada, and partly because of this there is as yet no definition which is universally accepted by Aboriginal 
people (McGregor, 2004a). TEK is a Western construct used to describe the lifeways of Aboriginal people in relation to the environment and its name reflects this (LaDuke, 1999).

The Earth Keepers program has at least partially sidestepped the controversy around the term "TEK" by not using that label in its written materials. Instead, a number of alternative terms are used interchangeably which reflect to some degree both the variety of Aboriginal conceptualizations of this knowledge and the Aboriginal origins from which it is derived. Terms used by the program include: ancestral knowledge, original knowledge, traditional teachings, cultural knowledge, and Indigenous knowledge. Such terms are intended to be more readily accessible to many Aboriginal community members who may not be familiar with the externally derived concept of TEK. Terms used throughout the program in general have been chosen to be commonly understood and easily recognizable at the community level. Using this approach throughout the guides and manuals for the Earth Keepers program reinforces its community level applicability. Such Aboriginal applications of the terminology will hopefully also influence how terms are applied in the field of TEK. In particular, they may serve to forge stronger links between outside academic discussions of TEK theory and the ground-level experiences of those who apply traditional knowledge in communities. This effort reflects an innovative strategy to link broader level initiatives with practical work at the community level.

\section{Traditional Knowledge Transmission}

There are many ways that traditional knowledge can be transmitted from generation to generation in First Nations communities (Wheeler). These include storytelling, dancing, singing, conducting ceremonies, hunting, gathering medicine, doing arts and crafts, or participating in any activity that brings people together to share ideas and knowledge (Wilson \& Harris). Lewis Cardinal (182) observes that, "Our Indigenous cultures are rich with ways of gathering, discovering and uncovering knowledge. They are as near as our dreams and as close as our relationships". Such activities were the normal and natural way in which traditional knowledge was shared in the community. Many of these modes of transmission exist in First Nations communities to varying degrees today. The Earth Keepers training provides an opportunity for this kind of sharing of experiences, ideas and knowledge among individuals and communities. The Earth Keepers approach promotes a high degree of networking (oral 
tradition) among participants. When working with First Nations it is often most productive to utilize these familiar methods of sharing traditional knowledge. Bringing people together to share knowledge is an important way of ensuring the continuation of TK at the community level.

\section{Earth Keepers and Traditional Knowledge: Towards a Holistic Approach}

Another lesson that those involved in the traditional knowledge discourse may draw from the Earth Keepers approach is that neither traditional knowledge nor any other aspect of environmental concerns should be viewed in isolation. Rather, the connections between aspects need to be understood, and the impacts of decisions in one area on other areas should be carefully considered. This is understood to be a holistic approach; it is one of the defining characteristics of TK from an Aboriginal perspective (Cajete; Clarkson et al.).

The Earth Keepers program makes every effort to put this holistic approach into practice by considering a whole range of community issues and exploring how they relate to the program (and vice versa). The inclusion of traditional knowledge in the educational portion of the program is a starting point for this concept. This Aboriginal-envisioned education involves a culture-based curriculum which reaffirms and reinstates traditional world views, philosophies, values, lessons, teachings, stories, etc. Traditional knowledge provides the theoretical framework and the philosophical foundation for the Earth Keepers.

The Earth Keepers training includes education and awareness components and emphasizes the link between solid waste management and broader issues in community well-being. The program relates the "environment" to issues in areas such as health, governance and community development. A key message is that solid waste management is not an isolated activity; it is part of the social fabric and is dependent on other initiatives, just as other initiatives may become dependent on the Earth Keepers program. Participants also learn that community cooperation, not just internally but among First Nations as well, is just as important as the specific content they are receiving in the training.

Increasing the role of traditional knowledge in education and training programs is potentially a considerable opportunity for revitalizing traditional knowledge as part of new and more progressive systems of environmental management in various contexts, including solid waste 
management. In recognition of this, the Earth Keepers program devotes significant energy to traditional knowledge and its application in solid waste management.

\section{Traditional Knowledge as a Circle}

There is considerable concern over the potential disappearance of traditional knowledge as Elders pass on (Johnson). While such concerns are certainly not groundless, there are other ways to view traditional knowledge and its sources. The Earth Keepers program demonstrates this in its approach to community education and awareness. In the Earth Keepers approach, children are essential participants in the process, and are at times given the role of teachers in the community. Children, as well as other members of the community including midwives, farmers, trappers, hunters, etc., are to learn aspects of traditional knowledge, waste management and community development and pass that message on to others in the community, including their parents and other adults. While this approach makes good sense at the community level, it is an approach not normally seen in the discourse on traditional knowledge, where the main experts are those with academic training and/or recognition as community Elders.

This way of understanding and applying traditional knowledge at the community level introduces a key feature of Aboriginal world view: the circle. Traditional knowledge actually works in a circle rather than in a linear fashion (Cajete). It is not passed simply from Elders to youth, but from children back to Elders as well, as children have insights that adults do not have.

\section{Contribution of the Earth Keepers Program to Capacity Building}

One of the main reasons behind the creation of the Earth Keepers program was to develop First Nations capacity to deal with solid waste management within their communities. As noted earlier, current methods of dealing with waste management concerns were inadequate; a new approach was needed which recognized each community's own abilities to resolve problems. The initiation of the Earth Keepers program has therefore been a conscious attempt to empower communities to "do it themselves". It represents a deliberate move away from highly technical training programs that require communities to continually rely on external experts, yet at the same time allows communities to access 
technical and management expertise as required. Communities can also share experiences with each other, so as to benefit from the knowledge of each others' successes and mistakes. Using Earth Keepers, communities are able to make their own informed decisions, rather than having their "solutions" designed for them.

Central to the incorporation of community traditional knowledge in the Earth Keepers program is the idea that the program is living. Its current form represents only a beginning; it will continue to evolve as more First Nations people take the training and provide feedback to continue the program's development. The program is designed and delivered in such a fashion that feedback from communities is immediate, and adjustments can be made following the completion of each module.

One of the most intriguing features of the Earth Keepers program is its insistence on traditional knowledge playing a vital role in community capacity building. The program framework starts from the premise that communities have knowledge, experience and expertise; collectively they know a great deal about solid waste management. The communities also possess what most (if not all) training programs cannot deliver: traditional knowledge. The Earth Keepers program is built upon the assumption that Aboriginal traditional knowledge will contribute to the planning process and waste management plan. Communities will not have to seek this knowledge externally (though in some cases they may have to relearn it, perhaps from other communities). In many cases they may simply need to apply what they already know. The Earth Keepers program recognizes the complexity of this issue and invests significant effort into having participants realize that much of the knowledge they need already exists in their communities.

The Earth Keepers program also realizes, however, that communities are diverse in terms of their experience with waste management issues. The program therefore provides a forum where communities can share knowledge and those who possess more capacity in certain areas can assist those with less. All participants benefit, as communities with a greater degree of capacity receive support and encouragement for their efforts while communities that require more assistance receive much needed training.

Such processes are designed to reinforce knowledge and skills that already exist at the community level (including traditional knowledge). They facilitate a sense of community and shared experience among 
participating First Nations. Communities learn from each other and reduce the need for expensive external technical experts (consultants). This does not entirely exclude the need for external experts, as communities are still expected to call upon them when required, but are not bound to rely solely upon them.

The Earth Keepers program can thus be described as a process for helping communities help themselves to get where they want to be. The program itself is not the solution. It is simply a tool for facilitating problem solving and empowerment in communities.

\section{Overview of Participant Responses}

Having seen that, at least in theory, the Earth Keepers program is making every effort to address the Agenda 21 objectives mentioned earlier, the question remains as to whether the community participants in the program were satisfied with its achievements. As described in the original overview report on this program (OFNTSC 2002), twelve Earth Keepers participants were interviewed on the subject of their experiences in the program, using an open interview style. Interviews ranged from 45 minutes to an hour. Discussion revolved around four key areas: strengths and weaknesses of the program; instructional approach; incorporation of TK; and sustainability of capacity building.

Overall, it was found that participants valued the training and perceived significant benefits for themselves and for their communities. The value of traditional knowledge was also recognized and participants felt that the incorporation of traditional knowledge in solid waste management planning improves the chances of sustainability. Participants felt that the message that traditional knowledge is important comes through very strongly in the program. However, they also noted that few practical strategies are provided to guide participants through the process of utilizing traditional knowledge in their own planning processes. Participants were left wanting access to more community examples and expertise in this area. It was nonetheless recognized that the program is a living program and will improve over time.

One of the most rewarding aspects of the training described by participants was the opportunity to network and collaborate with other First Nations. Making contacts and sharing experiences with others in similar situations improved the quality of the training significantly over just having the trainers present. 
In general, participants were pleased with their experience with the Earth Keepers training. Areas for improvement focus on balancing trainers' technical expertise with community knowledge. The delivery of training will be improved with creativity and innovation. Participants noted that OFNTSC has already taken steps to improve the process with each training session held.

\section{In Summary}

The Earth Keepers Solid Waste Management Planning Program is a forward-looking initiative focusing on the training of Aboriginal participants in the development and implementation of solid waste management programs in First Nation communities in Ontario. It represents a significant departure from conventional, top-down approaches to environmental problem solving in three main ways:

- $\quad$ First, Aboriginal people have been meaningfully involved in program development from the outset (the program was designed for the most part by Aboriginal people). First Nation communities were given the opportunity to provide input and direction as to what the program should look like so as to benefit those communities most effectively.

- Second, the program aims to utilize Aboriginal traditional knowledge throughout all aspects of training, plan development, and plan implementation. Aboriginal traditional knowledge covers all aspects of First Nation community life, and as such makes it necessary to consider links and relationships among different aspects of the environment. This holistic approach to thinking is key to sustainable development and makes even greater the potential contribution of traditional knowledge. Despite this, few programs prior to Earth Keepers have made similar connections.

- Third, the program takes a community-centered approach, where great value is placed not only on traditional knowledge but on community experience in general. It assists participants in drawing on existing community knowledge wherever possible, and building on that capacity where necessary. Rather than simply presenting communities with externally derived information and solutions, it requires each community to utilize and build upon its strengths so that in the end it will have developed the capacity to handle its own solid waste 
management issues. This community-centered approach will tend to have positive results for community development as a whole and not just in the area of solid waste management.

As with any recently created major program, one of the greatest challenges lies in implementing the theory and ensuring that goals and objectives are realized. OFNTSC has found that in its initial implementation stages, the program was well received but did not meet all participants' expectations. In foreseeing this eventuality, however, OFNTSC has built in a process for obtaining participant feedback such that improvements to the program are made following each training session. Having completed three rounds of training since 2000 (for several years there was a gap in delivery due to lack of funding, but the program is now being advanced with renewed enthusiasm), it is important to reflect upon the experience and perspectives of the program participants to continually improve capacity development. During the initial assessment of the program conducted in 2000 (OFNTSC, 2002), participants stated that although they would definitely recommend the program to others, its delivery needed to improve to match its theory in two key areas:

- the utilization of traditional knowledge in all areas of the program, rather than just being discussed at the beginning, and

- the balancing of trainers' knowledge in both community experience and technical expertise.

Given that improvements in these and other areas will be made, participants have thus far responded highly positively to the program. Many have felt that it was a "transforming experience" which renewed their sense of value as members of Aboriginal communities. Many also stated that one of the most positive aspects of the training was the opportunity to cooperate not only with other members of their own community on pressing issues, but also with representatives from other communities. The Earth Keepers program, while focusing on resolving specific problems in a particular area, at the same time draws First Nations together by strengthening networks among them.

By consistently obtaining and responding to constructive participant feedback such as this, OFNTSC strives to produce a dynamic, evolving program which will continue to meet the needs of communities, even as such needs change in the future. 


\section{Discussion: Traditional Knowledge in Sustainable Development}

The Earth Keepers Solid Waste Management Planning Program, while not without its challenges, addresses key aspects of sustainable development to ensure maximum success over the long term. The Brundtland report, the Convention on Biological Diversity, Agenda 21 and other declarations emanating from international fora, have called for the involvement of Indigenous peoples in addressing the environmental and sustainability challenges that face them. This represents a departure from the development model of "experts" designing and implementing solutions for local communities (Sillitoe and Bicker). This is a welcome change for Aboriginal peoples in Canada, where historically, "Canada's approach to First Nations has been one of paternalism and assimilation" (Croal and Darou 84). The relationship between Aboriginal and nonAboriginal society (particularly the state) is beginning to move to a stage of renegotiation and revitalization of Aboriginal peoples as nations (RCAP; 1996b). This broader context of the history of Aboriginal/nonAboriginal relations influences sustainable development efforts. Colonial history has produced a healthy skepticism among Aboriginal peoples of "development" initiatives designed to "help" them, particularly since development in Canada has meant the unsustainable development of environmental and natural resources (Croal and Darou RCAP; 1996a). Aboriginal people in Canada are interested in "development", but not at the expense of identity, culture, and traditionally sustainable economies (RCAP; 1996b). Aboriginal peoples want to be in control of development and define it on their terms as part of realizing the goals of self-determination.

The development movement that advocates inclusion of traditional knowledge recognizes that TK is valuable and can contribute to ensuring sustainability; science and technology do not have all the answers (and perhaps caused some of the problems in the first place). Aboriginal and non-Aboriginal people have something to learn from each other: "One of the central tenants of the indigenous knowledge movement is that scientists have something to learn from local practices too; we should have a two way flow of information, drawing on the combined strengths of different cultural traditions" (Sillitoe 113).

To date, inequalities in the power relationship between Aboriginal and non-Aboriginal people in Canada have impeded the consideration of TK in sustainable development (Ellis; McGregor, 2004a; Nadasdy, 2006). Indigenous scholars and activists in Canada have pointed out that the 
simple "integration" of TK into western-derived sustainable development initiatives has the potential to continue the ongoing colonization process (Battiste and Henderson, McGregor 2004a; Simpson; Wavey). As part of this, there has been a long history of TK exploitation among development agencies, and Aboriginal peoples are understandably wary of sharing traditional knowledge beyond their communities (Ellen). The protection of $\mathrm{TK}$ is thus of utmost concern to Aboriginal peoples in Canada (Brascoupe and Mann; Crowshoe). As such there has emerged a strong movement, both internationally and in Canada, to protect TK. Aboriginal organizations are increasingly proactive in developing protocols to ensure such protection (FNC).

Nevertheless, Aboriginal peoples indeed welcome the recognition of their knowledge in sustainable development settings, though some skepticism remains (Posey). Aboriginal peoples, and an increasing number of TK and development advocates, are therefore calling for more than simply having Aboriginal peoples "participating" or getting "involved" in sustainable development initiatives, but instead moving toward a model of partnership and collaboration (Cleveland and Soleri). As one northern researcher recently put it:

What we've learned is that you can't have a whole project and take a day or a week to try to work in a traditional-knowledge component.... It has to be from beginning to end, working together all the way. Before you even have a proposal, you need to get that working relationship started. (Gearheard in Gregoire 26)

There is a final observation to make in regards to the experience of Earth Keepers participants, and that concerns holism in environmental and development initiatives. At a recent Aboriginal environmental workshop, it was observed that Aboriginal peoples in Canada are focusing on the idea of "holistic development", rather than sustainable development (Lickers). From an Aboriginal perspective, development can only be sustainable if it takes into account the full range of costs, effects and benefits, both direct and indirect, associated with a given project. The Earth Keepers Program makes this critical distinction in part due to recommendations made by participants. TK affects all parts of an individual's and a community's life; it is not adequate to focus on a single area such as solid waste management. Any meaningful progress in sustainable development involving Aboriginal people will occur through a holistic approach which considers all facets of Aboriginal life. 
The opportunity for such dialogue has been catalyzed by international efforts mentioned earlier such as the Brundtland report, the Earth Summit, and the WSSD. The Indigenous presence on the international scene has in response increased significantly in recent decades (Stevens; Washnawatok). The UN Declaration on the Rights of Indigenous Peoples can perhaps be seen as the latest international achievement on Aboriginal issues, yet it in turn represents a new and important starting point for establishing appropriate goals and processes for engaging Indigenous peoples on issues that affect their lives and lands. The Earth Keepers program (along with a few others across Canada, such as Labrador's Ashkui project - see Sable et al.- which to varying degrees address similar issues) represents an early and promising manifestation of this engagement, and one from which it is hoped valuable lessons will be drawn in the move towards global sustainability.

\section{Conclusion: Embracing Traditional Knowledge in the Move Towards Decolonizing Programs and Institutions}

The Earth Keepers program has taken the first step in decolonizing its waste management efforts by incorporating TK in its development and implementation. However, scholars have argued that current ERM regimes require re-ordering to truly address Aboriginal peoples' involvement (Natcher et al., Stevenson, 2005; Wyatt). In order for Aboriginal ERM processes to flourish, Aboriginal peoples must be part of the governance system - they must in fact be decision makers. The current level of control of state-managed systems "... continues to limit the extent to which First Nations are empowered to propose and implement change.... the pervasiveness of state management has in effect perpetuated historical conditions where First Nations governments have gained little autonomy in the management of lands and resources (Natcher et al. 277). As Aboriginal peoples begin to assert their own laws, values, knowledges and traditions in ERM, state institutions must also reform via decolonizing processes to effectively accommodate Aboriginal interests.

The incorporation of Aboriginal interests into ERM must be much more than an add-on or an afterthought. Rather than merely incorporating Aboriginal interests, therefore, some strategies for decolonizing institutional frameworks must involve the promotion of Aboriginal knowledge as being equally as valid as Western knowledge. Most current institutions and programs are based on a Western framework; merely inserting components of Aboriginal knowledge at various convenient 
points will fragment Aboriginal knowledge and distort, and possibly destroy, its meaning (Stevenson, 2006). The voice of Aboriginal peoples in ERM systems can be adequately heard only if Aboriginal knowledge is given the opportunity to flourish alongside Western knowledge, rather than trying to contain it within Western knowledge.

The dominance of Western derived ERM regimes makes it a significant challenge just to accommodate TK, even in co-management contexts, let alone put it on an equal footing with Western knowledge. It therefore seems likely that entirely new institutions and/or programs will have to be developed to meet these new challenges and support Aboriginal goals for self-determination. Practitioners in the fields of environmental and resource management, as well as Aboriginal people themselves, are demanding that TK play an increasingly important role in the development and implementation of any legislation, policy and management regimes that impact Aboriginal lands and territories. One of the most important decolonization strategies that can be implemented is to support the emergence and establishment of Aboriginal environmental governance based on the worldview, traditions, values and knowledge of Aboriginal peoples themselves.

\section{Notes}

1. The Gwich'in Renewable Resources Board (GRRB) was established under the guidance of the Gwich 'in Comprehensive Land Claim Agreement (GCLCA) as the main instrument of wildlife, fish and forest management in the Gwich'in Settlement Area (GSA). (http://www. grrb.nt.ca/aboutus.htm)

2. Gwich'in local and traditional knowledge has been used to identify management issues, plan research and develop management plans. Long-term development impacts on the northern environment will be monitored using local knowledge. Gwich'in knowledge is also to be used when developing wildlife management plans, protected area strategies and land and water use permit processes. (http://www.grrb.nt.ca/traditionalknowledge.htm)

3. The Nunavut Wildlife Management Board (NWMB) mandate is to help ensure the protection and wise use of wildlife and wildlife habitat for the long-term benefit of Inuit and all citizens of Nunavut and Canada. (http://www.nwmb.com/english/about_nwmb/ about_nwmb.php)

4. In Canada, First Nations is a frequently used term describing Aboriginal peoples according to their traditional political organizational structure. The term refers to the fact that, prior to the "Indian bands" structure created through government colonization processes, Aboriginal peoples in Canada were organized into distinct nations, and operated with the full sovereignty that other nations around the world continue to enjoy. Aboriginal people in Canada continue to strive to regain much of that sovereignty as they negotiate with Canadian governments for increasing control over areas such as local governance, health, law enforcement, and education. 
5. Indian and Northern Affairs Canada (INAC) is the Government of Canada department primarily responsible for meeting the Government of Canada's constitutional, treaty, political and legal responsibilities to First Nations. Increasingly, INAC's role has become one of facilitating change and bringing together the partners and interest needed to implement Gathering Strength - Canada's Aboriginal Action Plan. INAC works collaboratively with First Nations to deliver a variety of programs, services, and funding support. (For more information, go to www.inac.ca.)

6. Note that in this paper, the term "traditional knowledge" is used with the intention of being more generic than the controversy-laden "TEK". As well, though it still contains the Western-derived word "traditional", this term is understood by many and is consistent with the language used in Agenda 21.

\section{Works Cited}

Assembly of First Nations (AFN). 1993. "Environment." In Assembly of First Nations. Reclaiming Our Nationhood: Strengthening Our Heritage. Report to the Royal Commission on Aboriginal Peoples. AFN, Ottawa, ON. pp. 39-50.

Battiste, M., and Henderson, J. 2000. Protecting Indigenous Knowledge and Heritage: A Global Challenge. Purich Publishing, Saskatoon, SK. 324 pp.

Berkes, F. 1999. Sacred Ecology: Traditional Ecological Knowledge and Resource Management. Taylor and Francis, Philadelphia, PA. 209 pp.

Borrows. J. 2005. Crown and Aboriginal Occupations of Land: A History \& Comparison. Research Paper prepared for the Ipperwash Inquiry. The Honourable Sidney B. Linden. Commissioner. Government of Ontario. Toronto, ON, 85 pp. Available online: http://www. attorneygeneral.jus.gov.on.ca/inquiries/ipperwash/policy_part/index.html [Accessed April 2009].

Brascoupe, S., and Mann, H. 2001. A Community Guide to Protecting Indigenous Knowledge. Indian and Northern Affairs Canada/Minister of Public Works and Government Services, Ottawa, ON.

Cajete, G. 2000. Native Science: Natural Laws of Interdependence. Clear Light Publishing, Sante Fe, NM.

Cardinal, L. 2001. "What is an Indigenous Perspective?" Canadian Journal of Native Education 25(2):180-182.

Centre for Indigenous Environmental Resources (CIER). 2005. Environmental Issues Research Report. CIER, Winnipeg, MB. (www.CIER.ca, accessed June 2008)

Chiefs of Ontario Working Group on Nationhood and Sustainability. 1997. "Nationhood and Sustainability Framework." In Minister of Indian Affairs and Northern Development. Towards Sustainable Development: A Strategy for the Department of Indian Affairs and Northern Development. Volume II - Part 4. Minister of Public Works and Government Services Canada, Ottawa, ON.

Clarkson, L., Morrrissette, V., and Regallet, G. 1992. Our Responsibility to the Seventh Generation: Indigenous Peoples and Sustainable Development. International Institute for Sustainable Development, Winnipeg, MB. 88 pp.

Cleveland, D., and Soleri, D. 2002. "Indigenous and Scientific Knowledge of Plant Breeding: Similarities, Differences and Implications for Collaboration." In Sillitoe, P., Bicker, A., and Pottier, J. (eds.). Participating in Development: Approaches to Indigenous Knowledge. ASA Monographs 39. Routledge, New York, NY.

Commissioner of the Environment and Sustainable Development. (CESD). 2005. Report of the Commissioner of the Environment and Sustainable Development to the House of Commons, Chapter 5: Drinking Water in First Nations Communities. Office of the Auditor General of Canada, Ottawa, ON. 34 pp. 
Croal, P., and Darou, W. 2002. "Canadian First Nations' Experiences with International Development." In Sillitoe, P., Bicker, A., and Pottier, J. (eds.). Participating in Development: Approaches to Indigenous Knowledge. ASA Mongraphs 39. Routledge, New York, NY.

Crowshoe, C. 2005. Sacred Ways of Life: Traditional Knowledge. Prepared for the National Aboriginal Health Association. Ottawa, ON. http://www.naho.ca/firstnations/english/ documents/FNC-TraditionalknowledgeToolkit-Eng.pdf.

Davis, L., O’Donnell, V., and H. Shpuniarsky. 2007. “Aboriginal-Social Justice Alliances: Understanding the Landscape of Relationships through the Coalition for a Public Inquiry into Ipperwash.” International Journal of Canadian Studies 36:95-119.

Doyle-Bedwell, P., and Cohen, F. 2001. "Aboriginal Peoples in Canada: Their Role in Shaping Environmental Trends in the Twenty-first Century." In Parson, E. (ed.). Governing the Environment: Persistent Challenges, Uncertain Innovations. University of Toronto Press, Toronto, ON. pp. 169-206.

Duckworth, G., Walker, J., McCrea, R., Turner, J., and J. Batise. 1999. Final Report of the Moose River Basin Environmental Information Partnership Steering Committee. Ontario Ministry of Natural Resources, Peterborough, ON. 43 pp.

Elijah, R. 1997. "Youth Perspective. Nationhood and Sustainability Framework." In Minister of Indian Affairs and Northern Development. Towards Sustainable Development: A Strategy for the Department of Indian Affairs and Northern Development. Volume II - Part 4. Minister of Public Works and Government Services Canada, Ottawa, ON.

Ellen, R. 2002. "Deja Vu, All over Again: Reinvention and Progress in Applying Local Knowledge to Development.” In Sillitoe, P., Bicker, A., and Pottier, J. (eds.). Participating in Development: Approaches to Indigenous Knowledge. ASA Mongraphs 39. Routledge, New York, NY.

Ellis, S. 2005. "Meaningful Consideration? A Review of Traditional Knowledge in Environmental Decision Making." Arctic 58(1): 66-77.

First Nations Centre (FNC). 2007. OCAP: Ownership. Control, Access and Possession. Assembly of First Nations, Ottawa, ON.

Gregoire, L. 2008. "Students of Weather.” Canadian Geographic 128(5):26.

Gunton, T., and Joseph, C. 2007. Toward a National Sustainable Development Strategy for Canada: Putting Canada On the Path to Sustainability within a Generation. David Suzuki Foundation, Vancouver, BC.

GRRB 2009. The Gwich 'in Renewable Resources Board (GRRB). Available on-line. http://www. grrb.nt.ca/ [Accessed June 2009].

Haudenosaunee Environmental Task Force (HETF).1999. Words that Come Before All Else: Environmental Philosophies of the Haudenosaunee. Native North American Traveling College, Cornwall Island, ON.

Higgins, C. 1998. "The Role of Traditional Ecological Knowledge in Managing for Biodiversity." Forestry Chronicle 74(3):323-326.

Houde. N. 2007. "The Six Faces of Traditional Ecological Knowledge: Challenges and Opportunities for Canadian Co-Management Arrangements." Ecology and Society 12 (2): $34 \mathrm{pp}$.

Johnson, M. (Ed). 1992. Lore: Capturing Traditional Environmental Knowledge. Dene Cultural Institute \& International Development Centre, Hay River, NWT.

Kassi, N. 1996. "A Legacy of Maldevelopment: Environmental Devastation in the Arctic.” In Weaver, J. (ed.). Defending Mother Earth: Native American Perspectives on Environmental Justice. Orbis Books, Maryknoll, NY. pp.72-84.

Kimmerer, R. 2002. "Weaving Traditional Ecological Knowledge into Biological Education: A Call to Action." Bioscience 52(5):432-438.

LaDuke, W. 1999. All Our Relations: Native Struggles for Land and Life. South End Press, Cambridge, MA. 241 pp. 
LaDuke, W. 1994. "Traditional Ecological Knowledge and Environmental Futures." In Colorado Journal of International Environmental Law and Politics. Endangered Peoples: Indigenous Rights and the Environment. University Press of Colorado, Niwot, CO. pp.127-148.

Lickers, H. 2008. Remarks made at the "Engaging First Nations in Environmental Strategies" Workshop. September 23. Turtle Island Environmental Resources, Toronto, ON.

Manseau, M., Parlee, B., and Ayles, G. 2005. "A Place for Traditional Ecological Knowledge in Resource Management." In Berkes, F. Breaking Ice: Renewable Resource and Ocean Management in the Canadian North. University of Calgary Press, Calgary, AB. pp. 141164.

McGregor, D. 2008. "Water Quality in the Province of Ontario: an Aboriginal Traditional Knowledge Perspective." In Hermon, E. (ed.). L'eau comme patrimoine : de la Méditerraneé à l'Amérique du Nord. Les Presses de l’Université Laval, Québec, QC. pp. 543-562.

McGregor, D. 2004a." "Traditional Ecological Knowledge and Sustainable Development: Toward Co-existence." In Blaser, M., and Feit, H. (eds.). In the Way of Development: Indigenous Peoples, Civil Society and the Environment. Zed Books, New York, NY. pp. 72-91.

McGregor, D. 2004b. "Coming Full Circle: Indigenous Knowledge, Environment and Our Future." American Indian Quarterly 28(3/4):385-410.

McGregor, D. 2000. "The State of Traditional Ecological Knowledge Research in Canada: A Critique of Current Theory and Practice.” In Laliberte, R., Settee, P., Waldram, J., Innes, R., Macdougall, B., McBain, L., and F. Barron (eds.). Expressions in Canadian Native Studies. University of Saskatchewan Extension Press, Saskatoon, SK. pp.436-458.

Menzies, C., and Butler, C. 2006. "Understanding Ecological Knowledge.” In Menzies, C. (ed.). Traditional Ecological Knowledge and Natural Resource Management. University of Nebraska Press, Lincoln, NE. pp.1-17.

Nadasdy, P. 1999. “The Politics of TEK: Power and the 'Integration' of Knowledge." Arctic Anthropology 36(1/2):1-18.

Nadasdy, P. 2006. "The Case of the Missing Sheep: Time, Space and the Politics of 'Trust' in Co-management Practice.” In: Menzies, C. (ed.). Traditional Ecological Knowledge and Natural Resource Management. University of Nebraska Press, Lincoln, NE. pp.127-151.

NAHO. (2007). Handbook and Resource Guide to the Convention on Biological Diversity. National Aboriginal Health Organization, Ottawa, ON.

Natcher, D \& Davis, S. 2007. "Rethinking Devolution: Challenges for Aboriginal Resource Management in the Yukon Territory." Society and Natural Resources 20: 3, 271-279.

National Forest Strategy Coalition (NFSC). 2003. National Forest Strategy (2003-2008). A Sustainable Forest: The Canadian Commitment. NFSC, Ottawa, ON. 27 pp. http://nfsc. forest.ca.

Nunavut Tunngavik. 2009. Nunavut Tunngavik (NT). Nunavut Land Claim Agreement. Available online: http://www.tunngavik.com/category/publications/nunavut-land-claims-agreement [Accessed June 2009).

O’Flaherty, R., Davidson-Hunt, I., and M. Manseau. 2008. “Indigenous Knowledge and Values in Planning for Sustainable Forestry: Pikangikum First Nation and the Whitefeather Forest Initiative." Ecology and Society 13(1): 6-16.

Ontario First Nations Technical Services Corporation (OFNTSC). 2008. About Us: Corporate Overview. http://www.ofntsc.org/about. (accessed 18 Aug 2008).

Ontario First Nations Technical Services Corporation (OFNTSC). 2002. The Earth Keepers Solid Waste Management Planning Program: an Overview. OFNTSC, Toronto, ON. 22 pp.

Pikangikum First Nation and Ontario Ministry of Natural Resources (PFN and OMNR). 2006. Keeping the Land: A Land Use Strategy for the Whitefeather Forest and Adjacent Areas. PFN, Pikangikum, ON, and OMNR, Red Lake, ON. 98 pp. 
Posey, D. 2002. "Upsetting the Sacred Balance: Can the Study of Indigenous Knowledge Reflect Cosmic Connectedness?" In Sillitoe, P., Bicker, A., and Pottier, J. (eds.). Participating in Development: Approaches to Indigenous Knowledge. ASA Mongraphs 39. Routledge, New York, NY.

Roberts, K. 1996. Circumpolar Aboriginal People and Co-Management Practice: Current Issues in Co-Management and Environmental Assessment. [conference proceedings]. Arctic Institute of North America and Joint Secretariat - Inuvialuit Renewable Resources Committees. Arctic Institute of North America, University of Calgary, AB. 172 pp.

Royal Commission on Aboriginal Peoples (RCAP). 1996a. "Lands and Resources." In Report of the Royal Commission on Aboriginal Peoples. Volume 2: Restructuring the Relationship. pp. 421-685. Canada Communication Group - Publishing Ottawa, ON. pp.421-685.

Royal Commission on Aboriginal Peoples (RCAP). 1996b. "Rekindling the Fire." In Report of the Royal Commission on Aboriginal Peoples. Volume 1: Looking Forward, Looking Back. Canada Communication Group - Publishing, Ottawa, ON. pp. 615-671.

Sable, T., Howell, G., Wilson, D., and P. Penashue. 2006. “The Ashkui Project: Linking Western Science and Innu Environmental Knowledge in Creating a Sustainable Environment." In Sillitoe, P. (ed.). Local Science vs Global Science: Approaches to Indigenous Knowledge in International Development. Berghahn Books, New York, NY. pp. 109-127.

Shackerof, J., and Campbell, L. 2007. "Traditional Ecological Knowledge in Conservation Research: Problems and Prospects for their Constructive Engagement." Conservation and Society 5(3):343-360.

Sillitoe, P. 2002. “Globalizing Indigenous Knowledge.” In Sillitoe, P., Bicker, A., and Pottier, J. (eds.). Participating in Development: Approaches to Indigenous Knowledge. ASA Mongraphs 39. Routledge, New York, NY. pp. 108-138.

Sillitoe, P., and Bicker, A. 2004. "Hunting for Theory, Gathering Ideology." In Bicker, A., Sillitoe, P., and Pottier, J. (eds). Development and Local Knowledge. Routledge, New York, NY. pp.1-18.

Simpson. L. 2004. "Anti-colonial Strategies for the Recovery and Maintenance of Indigenous Knowledge." American Indian Quarterly 28(3/4):373-384.

Spak, S. 2005. "The Position of Indigenous Knowledge in Canadian Co-management Organizations." Anthropologica 47(2):233-246.

Stevens, J. 1998. "Indigenous Activism at the U.N." Native Americas 15(1):46-53.

Stevenson, M. 2005. Traditional Knowledge in Sustainable Forest Management. Sustainable Forest Management Network, Edmonton, AB.

Stevenson, M. 2006. "The Possibility of Difference: Rethinking Co-management." Human Organization. 63:2, p. 167-180.

Teillet, J. 2005. The Role of the Natural Resources Regulatory Regime in Aboriginal Rights Disputes in Ontario. Research Paper prepared for the Ipperwash Inquiry. The Honourable Sidney B. Linden. Commissioner. Government of Ontario. Toronto, ON, 78 pp. Available online: http://www.attorneygeneral.jus.gov.on.ca/inquiries/ipperwash/policy_part/index. html [Accessed April 2009].

United Nations Department of Economic and SocialAffairs (UNDESA). 2004.Agenda 21: Chapter 26. Recognizing and Strengthening the Role of Indigenous People and their Communities. http://www.un.org/esa/sustdev/documents/agenda21/english/agenda21 chapter26.htm (accessed 18 Aug 2008).

United Nations General Assembly (UNGA). 2007. United Nations Declaration on the Rights of Indigenous Peoples. http://www.dd-rd.ca/site/_PDF/un/A_61_L67eng.pdf. (accessed June 28, 2008).

Usher, P. 2000. "Traditional Ecological Knowledge in Environmental Assessment and Management.” Arctic 53(2):183-193. 
Wavey, R. 1993. "International Workshop on Indigenous Knowledge and Community Based Resource Management: Keynote Address." In Inglis, J. (ed.). Traditional Ecological Knowledge: Concepts and Cases. Ottawa: International Program on Traditional Knowledge and International Development Research Centre: p11-16.

Washnawatok, I. 1997. "International Emergence: Twenty Years at the United Nations." Native Americas 14(2):13-21.

Wheeler, W. 2005. "Reflections on the Social Relations of Indigenous Oral Histories." In Lischke, U., and McNab, D. (eds.). Walking a Tightrope: Aboriginal People and their Representations. Wilfrid Laurier University Press, Waterloo, ON. pp.189-213.

White, G. 2006. Cultures in Collision: Traditional Knowledge and Euro-Canadian Governance Processes in Northern Land-Claim Boards. Vol. 59. No. 4. pp. 401-414.

Wilson, B., and Harris, H. 2005. “Tllsda Xaaydas K' Ancient Stories." In Fedje, D., and Mathewes, R. Haida Gwaii: Human History and Environment from the Time of Loon to the Time of the Iron People. UBC Press, Vancouver, BC. pp. 121-139.

World Commission on Environment and Development (WCED). 1987. Our Common Future. Oxford University Press, Oxford, UK. 454 pp.

World Intellectual Property Organization (WIPO). 2000. Roundtable on Intellectual Property and Traditional Knowledge. www.wipo.int/eng/meetings/1999/folklore/indexrt.htm.

Wyatt, S. 2008. "First Nations, Forest Lands, and 'Aboriginal Forestry' in Canada: From Exclusion to Co-management and Beyond." Canadian Journal of Forest Research. 38: 171-180. 